\title{
Morphology, Pathogenicity and Management of Coniella Fruit Rot (Coniella granati) on Pomegranate
}

\author{
Aysun Uysal, Şener Kurt*, Emine Mine Soylu, Merve Kara, Soner Soylu
}

Centre for Implementation and Research of Plant Health Clinic and Department of Plant Protection, Faculty of Agriculture, Mustafa Kemal University, 31040 Antakya/Hatay, Turkey

\begin{tabular}{|c|c|}
\hline ART ICLE INFO & A B S T R A C T \\
\hline $\begin{array}{l}\text { Research Article } \\
\text { Received 06 January } 2018 \\
\text { Accepted } 28 \text { March } 2018\end{array}$ & $\begin{array}{l}\text { One of the objectives of the study was to identify the fungus involved in fruit rot on } \\
\text { pomegranates in the Mediterranean Region of Turkey. The fungus designated as Coniella } \\
\text { granati (Saccardo) Petrak and Sydow based on morphological characteristics. The fungus } \\
\text { colonized the fruit after } 5 \text { to } 8 \text { days, followed by the appearance of fruit rot symptoms } \\
\text { leading to the formation of abundant pycnidia covering the peel. Secondly, the efficacy of }\end{array}$ \\
\hline $\begin{array}{l}\text { Keywords: } \\
\text { Coniella granati } \\
\text { Identification } \\
\text { Pomegranate } \\
\text { Fungicides-Fruit rot }\end{array}$ & $\begin{array}{l}\text { assays. Tebuconazole, boscalid }+ \text { pyraclostrobin and iprodione at } 1.0,25 \text {, and } 50 \mu \mathrm{gml}^{-1} \\
\text { concentrations, respectively, completely inhibited mycelial growth. In the azoxystrobin } \\
\text { and dodine, relatively higher concentrations required to inhibit mycelial growth. } \\
\text { Tebuconazole exhibited the greatest inhibition }(82.2 \%) \text { of mycelium growth. The EC } \mathrm{EC}_{50} \\
\text { values in mycelial growth of } C \text {. granati ranged from } 0.13 \text { to } 151.9 \text {. The highest EC } \text { gC }_{50} \\
\text { values occurred for tebuconazole }\left(0.13 \mu \mathrm{gml}^{-1}\right) \text {. Tebuconazole, boscalid+pyraclostrobin }\end{array}$ \\
\hline $\begin{array}{l}\text { Corresponding Author: } \\
\text { E-mail: senerk31040@ gmail.com }\end{array}$ & $\begin{array}{l}\text { and iprodione at } 200,10 \text { and } 5 \mu \mathrm{gml}^{-1} \text { concentrations, respectively, were the highly } \\
\text { effective in inhibiting conidial germination. Azoxystrobin exhibited a low effect }(61 \%) \\
\text { on conidial germination. The EC } \mathrm{E}_{50} \text { values on conidial germination of } C \text {. granati ranged } \\
\text { from } 0.2 \text { to } 28.7 \text {. Tebuconazole had the lowest EC } 50 \text { value, while boscalid+pyraclostrobin } \\
\text { exhibited the highest } \text { EC }_{50} \text { value. }\end{array}$ \\
\hline
\end{tabular}

DOI: https://doi.org/10.24925/turjaf.v6i4.471-478.1787

\section{Introduction}

Pomegranates (Punica granatum L.), which belongs to the family Punicaceae, are deciduous fruit trees originating from Iran to the Himalayas and are widely cultivated from the Mediterranean basin to Central Asia and countries of North and South America (Fernandez et al., 2014). After recent reports of the high antioxidant content of pomegranate fruit and juice, the pomegranate industry has increased considerably in Turkey and worldwide during the last decade as a profitable alternative for fruit growers. According to the Turkish Ministry of Food, Agriculture and Livestock, the cultivation area of pomegranate in Turkey has increased from 6700 hectare in 2005 to 30700 hectare in 2015, while the pomegranate fruit production has been increased to 446000 tonnes (TUIK, 2015). It is important to emphasize that the Mediterranean Region, including provinces Hatay, Adana, Mersin and Antalya, the main pomegranate-growing areas of the region, accounts for approximately $52.7 \%$ of the total pomegranate production in Turkey (TUIK, 2015).

Among the several yield-limiting diseases of pomegranate, fruit rots were one of the most important factors contributing to yield losses quantitatively, along with physiological disorders such as chilling injuries, husk scald, weight loss and shrinkage (Selcuk and Erkan 2014). Fruit decays are caused by various fungal pathogens such as Alternaria spp., Botrytis cinerea Pers., Aspergillus niger van Tiegh., Colletotrichum gloeosporioides (Penz.) Penz. and Sacc., Nematospora spp., Coniella granati (Sacc.) Petr. and Syd. (Synonym: Pilidiella granati Sacc.), Pestalotiopsis versicolor (Speg.) Steyaert, Syncephalastrum racemosum Cohn, Penicillium spp. and Rhizopus spp. (Hebert and Clayton 1963; Snowdon 1990; Bardas et al. 2009a,b; Pala et al., 2009; Jamadar et al., 2011; Thomidis and Exadaktylou 2011; Mirabolfathy et al., 2012; Palou et al., 2013; Kanetis et al., 2015; Munhuweyi et al., 2016; Alvarez et al., 2016).

During the summer of 2014, diseased fruits of pomegranate plant $\mathrm{cv}$. Hicaz in Hatay province in the Mediterranean region, one of the main production areas of Turkey, displayed typical symptoms of Coniella fruit rot in both pre- and postharvest seasons, especially following moist and cool conditions. Coniella granati, the causal agent of pomegranate fruit rot, has been reported from the Eastern Mediterranean region of Turkey (Yildiz and Karaca 1973), North Carolina (Hebert and Clayton 1963), Cyprus (Georghiou and Papadopoulos 1957; Richardson, 1990), Greece (Tziros and Tzavella-Klonari, 2008), 
California (Michailides et al., 2010), Spain (Palou et al., 2010; Palou et al., 2013), Israel (Levy et al., 2011), Iran (Mirabolfathy et al., 2012), Italy (Pollastro et al., 2016), and China (Chen et al., 2014). The disease can cause severe damage to pomegranate under favourable environmental conditions. This fungus requires a good rainfall, high humidity around 80 per cent and a temperature range of $22-32^{\circ} \mathrm{C}$ for its initial spread and development (Kumari and Ram, 2015). Over a decade ago, $C$. granati has been also identified as the causal agent of crown rot and postharvest rot in pomegranates in Turkey (Çeliker et al., 2012; Teksür et al., 2015).

Symptoms first became visible as small circular spots on the fruits, which later increased in size and developed into expanded brown lesions. Ultimately, the entire fruit turns brown to black after completely rotting. Then, black fungal pycnidia with characteristic large, elliptical, colourless, one-celled spores can develop on the surface of the arils, membranes, and surface of rind (fruit skin). Irrigation water and rain can spread the pycnidiospores from overwintered pycnidia onto the bark of the trees and the surface of young fruit and cause latent infections (Tziros and Tzavella-Klonari, 2008; Michailides et al., 2010; Munhuweyi et al., 2016).

The most effective and practical mean of controlling fruit rot of pomegranate is by the use of chemical fungicides. Of the fungicides, thiophanate methyl and tebuconazole have been commonly used to manage most of the pathogens causing fruit rot and shoot blight in fruit trees (Adaskaveg and Förster, 2002; Sharma, 2005; Thomidis, 2015). In addition, prochloraz, fludioxonil, tebuconazole + fluopyram and tebuconazole + trifloxystrobin were recommended to control storage diseases of pomegranate (Nerya et al., 2016). Prochloraz and tebuconazole fungicides were equally efficient in controlling storage rots but apparently, fludioxonil was less effective against Coniella granati (Nerya and Levin, 2015). However, very limited knowledge about the control of the fruit rot has prompted plant pathologists to focus on chemical control of pathogens causing Coniella fruit rot on pomegranate. In the recent past, new fungicides possessing new modes of action were developed. Of these fungicides, pyraclostrobin is among the newer members of the group of Quinone outside inhibitors (QoIs), a fungicide class, that was developed from natural fungicidal derivatives such as strobilurin $A$ ve oudemansin A (Bartlett et al., 2002). Boscalid is a new broad-spectrum fungicide belonging to the carboxamide (anilide) class of fungicides. These fungicides possess a different mode of action, the inhibition of the enzyme succinate ubiquinone reductase, also known as succinate dehydrogenase (SDH) playing a crucial role in the tricarboxylic cycle and the mitochondrial transport chain (Broomfield and Hargreaves, 1992). The SDHIs are classified as medium to high risk for resistance development because of their single-site mode of action.

The main objectives of this study were; (i) to identify the pathogen involved in fruit rot on pomegranates in the Mediterranean Region of Turkey, (ii) to evaluate in vitro the effectiveness of the fungicides iprodione, dodine, tebuconazole, azoxystrobin, and the mix boscalid+ pyraclostrobin on C. granati.

\section{Materials and methods}

Pathogen Isolation, Identification and Pathogenicity

During 2014-2015, pomegranate fruits showing characteristic necrotic lesions were obtained from local cv. Hicaz grown in symptomatic commercial orchards located in Hatay and Mersin provinces of Turkey. Disease assessments were performed at sometimes between September and November over 2 years. Thirty-eight pomegranate fruits were taken randomly and, transferred to the laboratory for isolation.

For fungal isolation, the epidermal tissues (approximately $5 \mathrm{~mm}$ ) of peels affected were surfacesterilized in $2 \% \mathrm{NaOCl}$ solution for $2 \mathrm{~min}$., rinsed twice in sterile distilled water, and dried between sterile filter papers. Small pieces of disinfested tissues were plated on potato dextrose agar (PDA) amended with $100 \mu \mathrm{g} \mathrm{ml}^{-1}$ streptomycin sulphate (Sigma Aldrich, St. Louis, MO) to inhibit bacterial growth. The plates were incubated at $25^{\circ} \mathrm{C}$ for 5 days in darkness. In order to obtain pure cultures, hyphal tips from the margin of each emerging fungal colony were subcultured on fresh PDA. Singlespore isolates of the fungus were prepared prior to use by means of the serial dilution method. Cultures of the fungus were maintained on dried Whatman no. 2 filter paper in refrigerator at $4^{\circ} \mathrm{C}$ until further use.

Fungal isolates were identified based on morphological criteria, such as colony appearance and morphological features of fruiting bodies and spores. The shape, colour, size of fruiting bodies and conidia were observed under a light microscope. Then, shape, length and width of 10 conidia were measured, and mean length and width were calculated. The fungus $C$. granati was identified based on fungal descriptions (Hebert and Clayton, 1963; Sutton, 1969; Barnett and Hunter, 1998; Van Niekerk et al., 2004; Palou et al., 2010). Morphological characterization of isolate was performed using monoconidial culture prepared on PDA.

To confirm identity of the fungus, pathogenicity tests were conducted on previously wounded pomegranate $\mathrm{cv}$. 'Hicaz' by pipetting 6 fruits with conidial suspension $\left(10^{6}\right.$ conidia per $\mathrm{ml}$ ) of $\mathrm{PCg} 1$ isolate of Coniella granati. For inoculum, conidial suspension was prepared by flooding the surface of the colony with sterile distilled water by scraping the surface of the plates using sterilized needle. The obtained suspension was then filtered through four layers of sterile cheesecloth. Tween $20(0.1 \%)$ was added to conidial suspension as wetting agent. The spore concentration of $C$. granati was adjusted to $10^{6}$ conidia $\mathrm{ml}^{-1}$ with the aid of a haemocytometer. Then, pomegranate fruits were surface-sterilized by immersing in $70 \%$ ethanol solution for $2 \mathrm{~min}$, later in $2 \% \mathrm{NaOCl}$ solution for $1 \mathrm{~min}$., and subsequently rinsing them three times in sterile distilled water for $2 \mathrm{~min}$. Disinfested fruits were allowed to dry in a laminar flow cabinet for 3 hours. Then, three points from the equatorial region of each fruits wounded with a sterile sharp needle. The wounds were approximately $2 \mathrm{~mm}$ in diameter and $5 \mathrm{~mm}$ in depth. Ten $\mu \mathrm{l}$ of spore suspension $\left(10^{6} \mathrm{spores} / \mathrm{ml}\right)$ was pipetted into each wound. Six control fruits were treated with the corresponding volume of sterile distilled water only. All fruits were placed in a plastic box (one fruit per box) that contained sterile paper soaked in sterile distilled water to maintain humidity. Inoculated and control fruits 
were incubated at room temperature with alternate light and dark periods of $12 \mathrm{~h}$ each. The experiment was evaluated 12 days after inoculation. Lesion development was evaluated in each point from the equatorial region of each fruit. The data were analysed by using statistical software (SPSS). Process means were separated using Duncan's Multiple Range Test $(\mathrm{p}=0.05)$.

\section{Effects of Some Fungicides on Mycelial Growth of C. granati}

The sensitivity of $\mathrm{PCg} 1$ isolate of $C$. granati against commercial formulations of five different fungicides such as dicarboximide fungicide iprodione, QoI fungicide azoxystrobin, guanidine fungicide dodine, DMI fungicide tebuconazole and mixture of SDHI fungicide boscalid and QoI fungicide pyraclostrobin (FRAC, 2016) was determined by comparing the mycelial radial growth of the fungus on PDA medium containing fungicide with the growth of the same isolate on a medium without the fungicide. Fungicides used in this study were commercial formulations of iprodione (Rovral 50WP, BayerCropScience, İstanbul, Turkey), azoxystrobin (Quadris SC 250 g/1, Syngenta, İstanbul, Turkey), dodine (Best Dodine 65 WP, Agrobest, İstanbul, Turkey), tebuconazole (Folicur 25 WP, BayerCropScience, İstanbul, Turkey) and boscalid+pyraclostrobin (Signum 33 WG, BASF, İstanbul, Turkey).

In order to determine the sensitivity of $C$. granati to these fungicides, autoclaved agar media were cooled to about $45^{\circ} \mathrm{C}$ and amended with appropriate volumes of the fungicide stock solutions to obtain the following desired concentrations: $0.01,0.1,0.5,1.0,10.0$ and $50.0 \mu \mathrm{gmL}^{-1}$ for iprodione; $0.01,0.1,0.5$ and $1.0 \mu \mathrm{gmL}^{-1}$ for tebuconazole; $0.01,0.1,1.0,10.0,50.0$ and $100.0 \mu \mathrm{gmL}^{-1}$ for dodine; $0.001,0.01,0.1,1.0,10.0,50.0$ and 100.0 $\mu \mathrm{gmL}^{-1}$ for azoxystrobin; $0.1,0.5,1.0,5.0,10.0,20.0$ and $25.0 \mu \mathrm{gmL}^{-1}$ for boscalid + pyraclostrobin. Unamended PDA plates served as the control. A 5-mm mycelial plug, with the aid of a cork borer, excised from the edge of an actively growing 5-d-old $C$. granati culture on PDA media, were placed upside down on the centre of $9 \mathrm{~cm}$ plastic Petri dishes containing fungicide-amended or unamended media. The plates were immediately sealed with Parafilm and incubated at $25^{\circ} \mathrm{C}$ for 7 days in darkness until the no-fungicide amended plates were 50 to $75 \%$ covered with mycelium (Kurt et al., 2003). For each concentration, colony diameter was measured in two perpendicular directions with the original diameter of the mycelial plug $(5 \mathrm{~mm})$ subtracted. The mean growth values were obtained and then converted to the inhibition percentage of mycelial growth in relation to the control treatment by using the formula, $\operatorname{MGI}(\%)=((\mathrm{dc}-\mathrm{dt})$ $/ \mathrm{dc}) \times 100$, dc and dt represent mycelial growth diameter in control and treated Petri plates, respectively. Three replicates of each fungicide concentration were used, and the experiment was performed twice on different days.

\footnotetext{
Effects of Some Fungicides on Spore Germination of C. granati

In this trial, $\mathrm{PCg} 1$ isolate of $C$. granati was used against selected some fungicides. Commercial formulations of five fungicides representing different chemical classes were evaluated for in vitro conidial inhibition of $C$. granati. In the study, fungicides were
}

added to $2.0 \%$ water agar medium after sterilization to produce different concentrations. For this purpose, 0.01, $0.1,0.5,1.0,3.0$ and $5.0 \mathrm{gmL}^{-1}$ concentrations for iprodione; 10.0, 50.0, 100.0 and $200.0 \mu \mathrm{gmL}^{-1}$ for tebuconazole; 5.0, 10.0, 20.0 and $50.0 \mu \mathrm{gmL}^{-1}$ for dodine; 5.0, 10.0, 50.0 and $100.0 \mu \mathrm{gmL}^{-1}$ for azoxystrobin; 0.01 , $0.1, \quad 0.5, \quad 1.0, \quad 5.0$ and $10 \mu_{g m L}^{-1}$ for boscalid +pyraclostrobin were used in experiment. Fungal cultures were grown on PDA, and incubated for 7 days at $25^{\circ} \mathrm{C}$ in the dark. A conidial suspension was prepared for the fungus by flooding the agar surface with $10 \mathrm{ml}$ of sterile distilled water and scraping with a sterile spatula. The resulting spore suspension was filtered through two layers of cheesecloth into a $250 \mathrm{ml}$ Erlenmeyer flask. The filtrate was diluted with sterilized distilled water and the conidial concentration was adjusted with a haemocytometer to $10^{6}$ conidia $\mathrm{ml}^{-1}$. Then, $100 \mu \mathrm{l}$ of conidial suspensions were spread onto $2 \%$ water agar plates supplemented with appropriate volumes of each fungicide. Conidia allowed germinating at $25^{\circ} \mathrm{C}$ for $20 \mathrm{~h}$ in darkness. Germination was quantified at three sites by counting 100 conidia per site under light microscope (Olympus BX51, Tokyo, Japan), using a micrometre. A conidium was scored as germinated if the germ tube had reached at least half the length of the conidium. The percent inhibition was calculated according to Abbott's formula: Inhibition $($ percentage $)=[(\mathrm{Gc}-\mathrm{Gt}) / \mathrm{GC})] \times 100, \mathrm{GC}$ and $\mathrm{Gt}$ represent the mean number of germinated conidia in control and treated Petri plates, respectively. Three plates for each concentration were used and the experiment was performed twice.

\section{Statistical Analysis}

The colony diameter values were subjected to analysis of variance, and means were compared by Duncan's multiple range test. The $\mathrm{EC}_{50}$ values (effective concentration that reduces spore germination or mycelial growth by $50 \%$ ) of the pathogen fungus $C$. granati to iprodione, azoxystrobin, dodine, tebuconazole and boscalid+pyraclostrobin were calculated using probit analysis applied to the percentage inhibition of mycelial growth or conidial germination as a function of the log of inhibitor concentrations. All data were subjected to oneway ANOVA using SPSS statistical software (SPSS Inc., Chicago, IL). Comparison of means was performed using the Duncan Multiple Range Test $(\mathrm{P}=0.05)$.

\section{Results}

Pathogen Isolation, Identification and Pathogenicity

In the survey conducted in the affected areas, initially, small circular spots on the fruits characterized disease symptoms. Later, these lesions increased in size and developed into expanded brown lesions (Fig. 1). Affected fruits rotted completely during storage causing yield losses of up to $50 \%$. In the later stages of disease development, abundant pycnidia covered the rind of rotted fruits.

Fungal colonies consisted of initially white mycelial growth, becoming olivaceous, and turning brown with age (Fig. 2). Microscopic examination of necrotic spots revealed that fungus produced white yellowish creamcoloured mycelium that formed large numbers of pycnidia after incubation at $25^{\circ} \mathrm{C}$ for 7 days. 


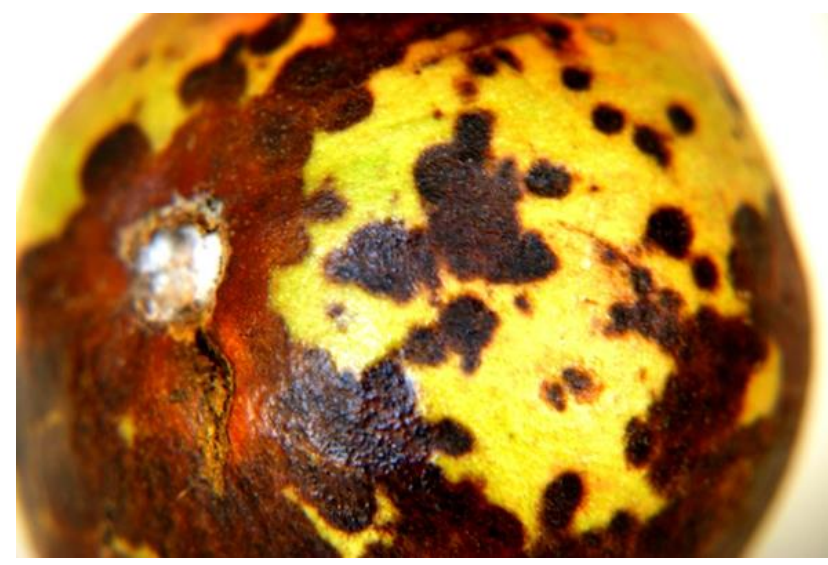

Figure 1 Characteristic symptoms of fruit rot caused by Coniella granati on pomegranate:, small circular spots, brown necrotic lesions and pycnidia on fruit

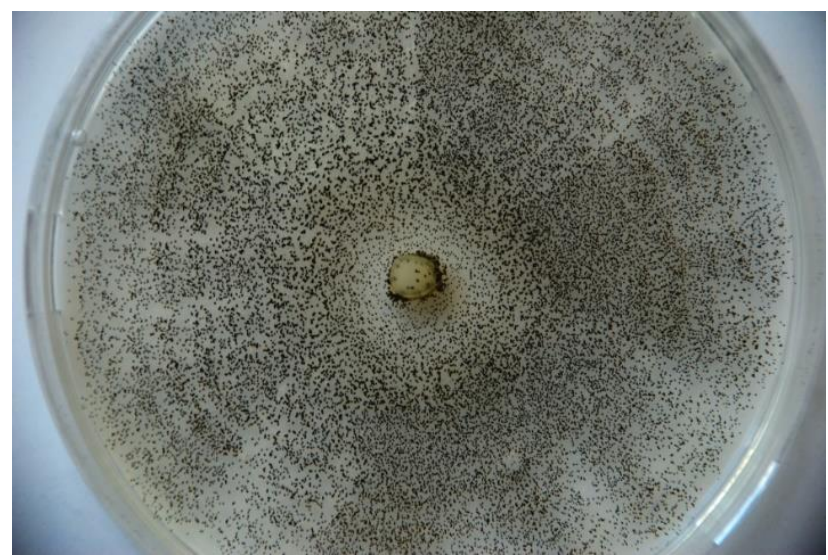

Figure 2 Coniella granati monoconidial culture isolated on PDA from pomegranate cv. 'Hicaz'. Plate diameter: 90 $\mathrm{mm}$. Single and clustered pycnidia visible in the colony center are diameter $92-178 \mu \mathrm{m}$ in diameter

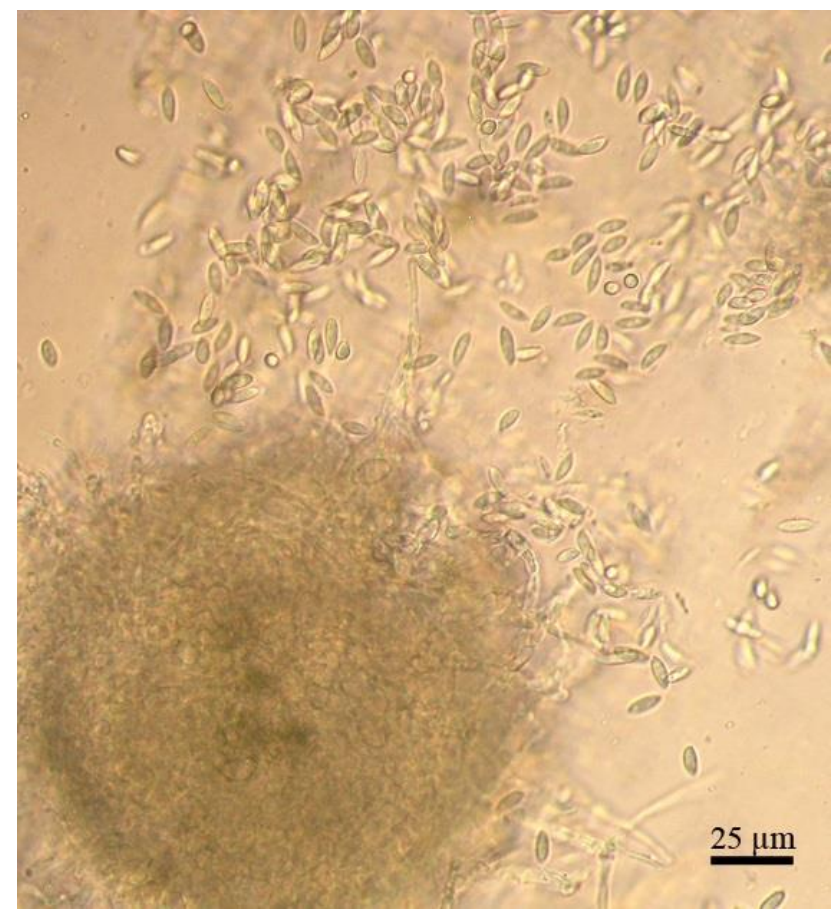

Figure 3 Pycnidium and conidia of Coniella granati from monoconidial PDA culture
Microscopic examination of necrotic spots revealed that pycnidia were globose, dark brown to black in colour, ranging from $92-178 \mu \mathrm{m}$ in diameter (Fig. 3). Conidia were hyaline, one-celled, elongate, and straight or slightly curved, $8.9-14.0 \times 2.7-3.8 \mu \mathrm{m}$, close to the dimensions given by Sutton (1980): 10-15×2.5-3.5 $\mu \mathrm{m}$. The fungus was identified as Coniella granati (Saccardo) Petrak and Sydow (synonym Pilidiella granati Saccardo). A total of nine isolates of the fungus were obtained. The pure culture of pathogen has been deposited in the Culture Collection of the Plant Health Clinic of Mustafa Kemal University as PCg1.

In the pathogenicity test, the results revealed that all fruits developed a high percentage of rots ranged from 55.7 to $100 \%$ (Fig. 4). Furthermore, the fungus was reisolated from all infected tissues, satisfying Koch's postulates. On pomegranate fruit, the fungus colonized the fruit after 5 to 8 days, followed by the appearance of fruit rot symptoms leading to the formation of abundant pycnidia covering the skin after 10 days. No decay was observed in control inoculations. To our knowledge, this is the first record of $C$. granati causing Coniella fruit rot on pomegranate in Eastern Mediterranean Region of Turkey.

Effects of Some Fungicides on Mycelial Growth of C. granati

The effects of different concentrations of some fungicides on the mycelial growth of $C$. granati are shown in Table 1. All fungicides except azoxystrobin were found to inhibit the growth of $C$. granati in a dosedependent manner. Of all fungicides tested, tebuconazole, boscalid+pyraclostrobin and iprodione at 1.0, 25, and 50 $\mu \mathrm{gml}^{-1}$ concentrations, respectively, completely inhibited mycelial growth of the pathogen. In the azoxystrobin and dodine treatments, relatively higher concentrations were required to inhibit mycelial growth as shown in Table 1. Among all fungicides tested, tebuconazole exhibited the greatest inhibition $(82.2 \%)$ of mycelium growth of $C$. granati at $0.5 \mathrm{\mu gml}^{-1}$ concentration. In order to obtain same level inhibition, 20-fold concentrations of boscalid+pyraclostrobin were used in the experiment. However, antifungal activity on the pathogen increased with increasing concentrations of these chemicals.

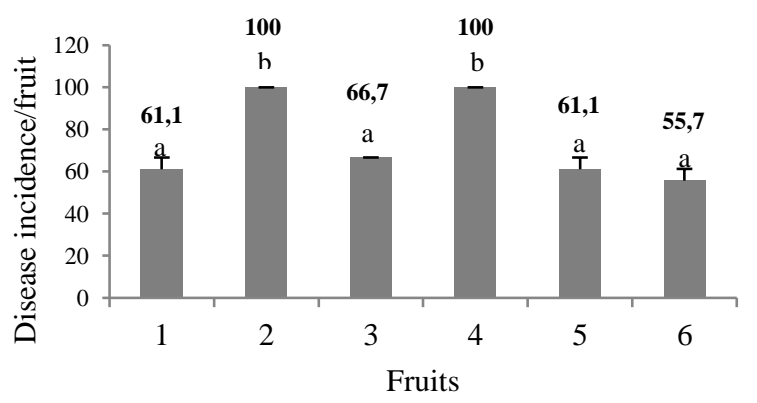

Figure 4 Occurrence of lesion produced 12 days after inoculation with $\mathrm{PCg} 1$ isolate of Coniella granati.

Different letters associated with bars within plant ages are significantly different according to Duncan Multiple Range Test at $\mathrm{P}=0.05$. Bar represent standard error of the mean 
Effective concentration $\left(\mathrm{EC}_{50}\right)$ values of each fungicide were also estimated by using probit analyses. The $\mathrm{EC}_{50}$ values for fungicides on mycelial growth of $C$. granati ranged from 0.13 to 151.9 (Table 1). The highest $\mathrm{EC}_{50}$ values of fungicides were recorded for tebuconazole $\left(0.13 \mu \mathrm{gml}^{-1}\right)$, followed by iprodione $\left(0.6 \mu \mathrm{gml}^{-1}\right)$ and boscalid+pyraclostrobin $\left(1.3 \mu \mathrm{gml}^{-1}\right)$.

Effects of Some Fungicides on Spore Germination of C. granati

Effects of different concentrations of fungicides on the conidial germination of $C$. granati were given in Table 2 . As observed in mycelial growth inhibition experiments, fungicides tebuconazole, boscalid+pyraclostrobin and iprodione were also found to be effective on conidial germination at 200, 10 and $5 \mu^{-1}$ concentrations, respectively. However, dodine completely inhibited conidial germination of $C$. granati unlike mycelial growth. This difference indicated that susceptibility for conidial germination the pathogen to dodine fungicide was higher than mycelial growth. On the other hand, complete inhibition of conidial germination of $C$. granati by the iprodione and boscalid+pyraclostrobin realized in lower concentrations than those of mycelial growth. Of the tested fungicides, azoxystrobin exhibited a low effect
$(61 \%)$ on conidial germination. Based on $\mathrm{EC}_{50}$ values estimated, boscalid+pyraclostrobin, iprodione and dodine were the most effective fungicides in inhibiting of conidial germination of $C$. granati. The $\mathrm{EC}_{50}$ values for fungicides on conidial germination of $C$. granati ranged from 0.2 to 28.7 (Table 2). For conidial germination, tebuconazole had the lowest $\mathrm{EC}_{50}$ value, while boscalid+pyraclostrobin exhibited the highest $\mathrm{EC}_{50}$ value.

\section{Discussion}

Fruit rots of pomegranate caused by $C$. granati have become the most important limiting factors in the production of pomegranate in Turkey and no effective control measure exists. In the most of the preharvest rotted fruits, Coniella granati was the main causal agent. The appearance of preharvest pomegranate rots is most likely attributed to applications of fertilizer and fungicide, windy weather during the summer and the semi-arid climate of Turkey. The evidence from these studies suggests a variety of factors related to the disease incidence and severity. The fungus was identified as Coniella granati (Saccardo) Petrak \& Sydow (synonym Pilidiella granati Saccardo). based on morphological characteristics (Hebert and Clayton 1963; Sutton 1969).

Table 1 Effect of different fungicides on mycelial growth of PCg1 isolate of Coniella granati

\begin{tabular}{|c|c|c|c|c|}
\hline Fungicides & Conc. $\left(\mu \mathrm{gml}^{-1}\right)$ & Colony diameter $(\mathrm{mm})^{\mathrm{z}}$ & Effect (\%) & $\mathrm{EC}_{50}$ value \\
\hline \multirow{7}{*}{ Iprodione } & 0.0 & $61.7 \mathrm{~g} \pm 1.7^{*}$ & 0.0 & \multirow{7}{*}{$0.6 \pm 0.09$} \\
\hline & 0.01 & $58.7 \mathrm{f} \pm 0.7$ & 4.7 & \\
\hline & 0.1 & $56.0 \mathrm{e} \pm 1.0$ & 9.0 & \\
\hline & 0.5 & $22.7 \mathrm{~d} \pm 0.3$ & 63.2 & \\
\hline & 1.0 & $11.3 \mathrm{c} \pm 0.3$ & 81.6 & \\
\hline & 10.0 & $5.0 \mathrm{~b} \pm 0.0$ & 91.9 & \\
\hline & 50.0 & $0.0 \mathrm{a} \pm 0.0$ & 100.0 & \\
\hline \multirow{5}{*}{ Tebuconazole } & 0.0 & $61.7 \mathrm{e} \pm 1.7$ & 0.0 & \multirow{5}{*}{$0.13 \pm 0.16$} \\
\hline & 0.01 & $55.3 \mathrm{~d} \pm 1.5$ & 10.3 & \\
\hline & 0.1 & $45.3 c \pm 0.9$ & 26.5 & \\
\hline & 0.5 & $11.0 \mathrm{~b} \pm 1.0$ & 82.2 & \\
\hline & 1.0 & $0.0 \mathrm{a} \quad \pm 0.0$ & 100 & \\
\hline \multirow{7}{*}{ Dodine } & 0.0 & $63.3 \mathrm{e} \pm 1.7$ & 0.0 & \multirow{7}{*}{$151.9 \pm 0.06$} \\
\hline & 0.01 & $60.0 \mathrm{~d} \pm 0.0$ & 5.1 & \\
\hline & 0.1 & $60.0 \mathrm{~d} \pm 0.0$ & 5.1 & \\
\hline & 1.0 & $55.7 \mathrm{c} \pm 0.7$ & 11.9 & \\
\hline & 10.0 & $41.7 \mathrm{~b} \pm 1.7$ & 34.2 & \\
\hline & 50.0 & $36.3 \mathrm{a} \pm 0.9$ & 42.6 & \\
\hline & 100.0 & $34.7 \mathrm{a} \pm 0.3$ & 45.2 & \\
\hline \multirow{8}{*}{ Azoxystrobin } & 0.0 & $66.7 \mathrm{e} \pm 1.7$ & 0.0 & \multirow{8}{*}{$>200 \pm 0.04$} \\
\hline & 0.001 & $62.7 \mathrm{~d} \pm 0.3$ & 5.9 & \\
\hline & 0.01 & $59.0 \mathrm{c} \pm 0.6$ & 11.4 & \\
\hline & 0.1 & $56.3 b \pm 0.7$ & 15.3 & \\
\hline & 1.0 & $54.3 b \pm 0.7$ & 18.4 & \\
\hline & 10.0 & $50.7 \mathrm{a} \pm 0.7$ & 24.0 & \\
\hline & 50.0 & $50.0 \mathrm{a} \pm 0.0$ & 24.9 & \\
\hline & 100.0 & $49.0 \mathrm{a} \pm 0.6$ & 26.4 & \\
\hline \multirow{8}{*}{ Boscalid+pyraclostrobin } & 0.0 & $59.3 \mathrm{~g} \pm 0.7$ & 0.0 & \multirow{8}{*}{$1.3 \pm 0.1$} \\
\hline & 0.1 & $50.3 \mathrm{f} \pm 0.3$ & 15.2 & \\
\hline & 0.5 & $38.3 \mathrm{e} \pm 0.9$ & 35.4 & \\
\hline & 1.0 & $30.3 \mathrm{~d} \pm 0.3$ & 48.9 & \\
\hline & 5.0 & $22.0 \mathrm{c} \pm 1.2$ & 62.9 & \\
\hline & 10.0 & $12.0 \mathrm{~b} \pm 1.5$ & 79.7 & \\
\hline & 20.0 & $4.7 a \pm 0.3$ & 92.1 & \\
\hline & 25.0 & $0.0 \mathrm{a} \pm 0.0$ & 100 & \\
\hline
\end{tabular}

z: diameter of fungal colony formed on PDA media treated with fungicides, *: Different letters associated with columns within concentrations are significantly different according to Duncan Multiple Range Test at $\mathrm{P}=0.05$ 
Table 2 Effect of different fungicides on spore germination of PCg1 isolate of Coniella granati

\begin{tabular}{|c|c|c|c|c|}
\hline Fungicides & Conc. $\left(\mu \mathrm{gml}^{-1}\right)$ & Spore Germination $(\%)$ & Effect $(\%)$ & $\mathrm{EC}_{50}$ value \\
\hline \multirow{7}{*}{ Iprodione } & 0.0 & $98.3 \mathrm{~g} \pm 0.9 *$ & 0.0 & \multirow{7}{*}{$0.2 \pm 0.8$} \\
\hline & 0.01 & $89.7 \mathrm{f} \pm 0.9$ & 8.8 & \\
\hline & 0.1 & $66.7 \mathrm{e} \pm 0.9$ & 32.2 & \\
\hline & 0.5 & $42.7 \mathrm{~d} \pm 1.5$ & 56.6 & \\
\hline & 1.0 & $20.7 \mathrm{c} \pm 0.7$ & 79.0 & \\
\hline & 3.0 & $11.0 \mathrm{~b} \pm 0.6$ & 88.8 & \\
\hline & 5.0 & $0.0 \mathrm{a} \quad \pm 0.0$ & 100.0 & \\
\hline \multirow{5}{*}{ Tebuconazole } & 0.0 & $99.0 \mathrm{e} \pm 0.9$ & 0.0 & \multirow{5}{*}{$28.7 \pm 0.2$} \\
\hline & 10.0 & $69.3 \mathrm{~d} \pm 1.2$ & 29.5 & \\
\hline & 50.0 & $52.0 \mathrm{c} \pm 2.3$ & 47.1 & \\
\hline & 100.0 & $17.7 \mathrm{~b} \pm 1.5$ & 82.0 & \\
\hline & 200.0 & $0.0 \mathrm{a} \quad \pm 0.0$ & 100.0 & \\
\hline \multirow{5}{*}{ Dodine } & 0.0 & $98.3 \mathrm{e} \pm 0.9$ & 0.0 & \multirow{5}{*}{$3.8 \pm 0.3$} \\
\hline & 5.0 & $40.3 \mathrm{~d} \pm 0.9$ & 59.0 & \\
\hline & 10.0 & $11.7 \mathrm{c} \pm 0.9$ & 88.1 & \\
\hline & 20.0 & $6.7 \mathrm{~b} \pm 1.2$ & 93.2 & \\
\hline & 50.0 & $0.0 \mathrm{a} \quad \pm 0.0$ & 100.0 & \\
\hline \multirow{5}{*}{ Azoxystrobin } & 0.0 & $98.3 \mathrm{c} \pm 0.9$ & 0.0 & \multirow{5}{*}{$1.1 \pm 0.1$} \\
\hline & 5.0 & $46.7 \mathrm{~b} \pm 1.7$ & 52.5 & \\
\hline & 10.0 & $41.7 \mathrm{a} \pm 0.9$ & 57.6 & \\
\hline & 50.0 & $39.7 \mathrm{a} \pm 0.3$ & 59.6 & \\
\hline & 100.0 & $38.3 \mathrm{a} \pm 0.9$ & 61.0 & \\
\hline \multirow{7}{*}{ Boscalid+pyraclostrobin } & 0.0 & $98.3 \mathrm{f} \pm 0.9$ & 0.0 & \multirow{7}{*}{$0.2 \pm 0.07$} \\
\hline & 0.01 & $89.0 \mathrm{e} \pm 0.6$ & 9.5 & \\
\hline & 0.1 & $68.7 \mathrm{~d} \pm 0.9$ & 30.1 & \\
\hline & 0.5 & $30.0 \mathrm{c} \pm 0.6$ & 69.5 & \\
\hline & 1.0 & $28.3 \mathrm{c} \pm 0.9$ & 71.2 & \\
\hline & 5.0 & $9.0 \mathrm{~b} \pm 0.6$ & 90.9 & \\
\hline & 10.0 & $0.0 \mathrm{a} \quad \pm 0.0$ & 100.0 & \\
\hline
\end{tabular}

*: Different letters associated with columns within concentrations are significantly different according to Duncan Multiple Range Test at $\mathrm{P}=0.05$

Rot symptoms observed on the pomegranate fruits affected by the Coniella rot in the region are confirmed by the results of Hebert and Clayton (1963), Richardson (1990), Tziros and Tzavella- Klonari (2008), Palou et al., (2010), Levy et al., (2011), Mirabolfathy et al., (2012), Chen et al., (2014) who reported $C$. granati as the pathogen causing fruit rot of pomegranate. It is generally agreed today that the causal agent $C$. granati (Saccardo) (an obligate synonym of Pilidiella granati according to MycoBank database) is one of the causes of the postharvest pomegranate decay (Hebert and Clayton, 1963; Labuda et al., 2004; Tziros and Tzavella-Klonari, 2008; Bardas et al., 2009).

C. granati has been also identified as the causal agent of crown rot and shoot blights in pomegranates trees (Thomidis and Exadaktylou, 2011; Çeliker et al., 2012). Furthermore, Koch's postulates were satisfied after reisolating the fungus from inoculated fruit that developed symptoms similar to those observed on fruit collected from orchards. Control fruits did not show any symptom of the disease.

To date, fungicides registered in pomegranate conventional production in Turkey were only mancozeb and tebuconazole. In the current study, sensitivity of $C$. granati obtained from pomegranate production in the Mediterranean Region of Turkey to five fungicides belonging to chemical groups with different modes of action was investigated in vitro. Thus, the results of the present study demonstrate that it provides valuable information about which fungicides could be of interest for future registration. In vitro studies about the inhibition of mycelial growth and conidial germination by $50 \%$ ( $\mathrm{EC}_{50}$ values) are a wide-used indicator of pathogen sensitivity to fungicides. In the present study, $\mathrm{EC}_{50}$ values of $C$. granati to a wide range of different fungicides were determined based on mycelial growth and conidial germination of the fungus.

In the present study, the $\mathrm{EC}_{50}$ values for fungicides on mycelial growth of $C$. granati ranged from 0.13 to 151.9 . Tebuconazole, with the highest $\mathrm{EC}_{50}$ value $\left(0.13 \mu \mathrm{gml}^{-1}\right)$, highly inhibited mycelial growth of $C$. granati, but azoxystrobin and dodine were considered as ineffective. This finding is consistent with results of Kumari et al., (2015) reporting that some DMI (triazoles) fungicides such as propiconazole, difenoconazole, flusilazole and hexaconazole, which take place in same chemical group with tebuconazole, were the most effective and completely inhibited the mycelial growth of the fungus.

Azoxystrobin is a fungicide, which has been commonly used around the world to protect field crops, fruits and vegetables. It is the leading strobilurin fungicide in FRAC Group 11. This fungicide inhibits mitochondrial respiration of pathogens by binding its active compound to Qo in the cytochrome bc1 enzyme complex (Complex III), thereby blocking electron transfer and halting ATP synthesis (Ypema and Gold, 1999; Barlett et al., 2002).

Based on $\mathrm{EC}_{50}$ values estimated, boscalid+pyraclostrobin, iprodione and dodine were the most effective fungicides in inhibiting of conidial 
germination of $C$. granati. Taking into account the statistical data, we can conclude that spore germination rate $(\%)$ are significantly $(\mathrm{P}=0.05)$ different according to Duncan Multiple Range Test. Pyraclostrobin from FRAC Group 11 belongs to quinone outside inhibitors or QoI fungicides, also called strobilurins, which are sitespecific. Boscalid from FRAC Group 7 is a completely new active ingredient belonging to the pyridinecarboxamides group of fungicides via a completely novel mode of action that interferes with the enzyme succinate ubiquinone reductase (complex II) in the mitochondrial electron transport chain.

\section{Conclusions}

All of this points to the fact that the data can provide important information related to the efficacy of different fungicides to control fruit rot of pomegranate. Such results suggest that boscalid+pyraclostrobin and tebuconazole could play a key role in fruit rot management in the near future and encourage their introduction into spray programs. Thus, in a previous study (Thomidis, 2014), it was concluded that pre-storage spray application with the fungicides tebuconazole and thiophanate methyl could reduce the percentage of postharvest fruit rots. Consequently, this information can be require designing the most effective fungicide spray schedules considering the optimum number of applications and fungicides selection in order to achieve both satisfactory control of the disease and reduced risk of resistance.

\section{Acknowledgment}

We thank Caner Kurt for providing the diseased plant material used for pathogen isolations from Silifke, Mersin.

\section{References}

Adaskaveg J, Förster H, 2002. New detection and management practices for brown rot of peach in California. Acta Horticult 592:637-643.

Alvarez LV, Groenewald JZ, Crous PW, 2016. Revising the Schizoparmaceae: Coniella and its synonyms Pilidiella and Schizoparme. Studies in Mycology 85: 1-34.

Bardas GA, Tzelepis GD, Lotos L, Karaoglanidis GS, 2009a. First report of Botrytis cinerea causing gray mold of pomegranate (Punica granatum) in Greece. Plant Dis 93:1346.

Bardas GA, Tzelepis GD, Lotos L, Karaoglanidis GS, 2009b. First report of Penicillium glabrum causing fruit rot of pomegranate (Punica granatum) in Greece. Plant Dis 93:1347.

Bartlett DW, Clough JM, Godwin JR, Hall AA, Hamer M, ParrDobrzanski B, 2002. The strobilurin fungicides. Pest Manag Sci 58(7):649-662.

Barnett HL, Hunter BB, 1998. Illustrated Genera of Imperfect Fungi. 4th ed. APS, St. Paul, Minnesota.

Broomfield PLE., Hargreaves JA, 2002. A single-amino acid change in the iron-sulphur protein subunit of succinate dehydrogenase confers resistance to carboxin in Ustilago maydis. Curr Genet 22:117-121.
Chen Y, Shao DD, Zhang AF, Yang X, 2014. First report of a fruit rot and twig blight on pomegranate (Punica granatum) caused by Pilidiella granati in Anhui province of China. Plant Dis 89:695.

Çeliker NM, Uysal A, Çetinel B, Poyraz D, 2012. Crown rot on pomegranate caused by Coniella granati in Turkey. Australasian Plant Dis. Notes 7:161-162.

Fernandez F, Legua P, Martinez R, Melgarejo P, Martinez JJ, 2014. Fruit quality characterization of seven pomegranate accessions (Punica granatum L.) grown in Southeast Spain. Sci Hortic 175:174-180.

FRAC Code List, 2016. Fungicides Sorted by Mode of Action (Including FRAC Code Numbering), pp. 1-10. http://www.frac.info/publication/anhang/FRAC\%20Code \%20List \%202016-final.pdf.

Georghiou GP, Papadopoulos C, 1957. A second list of Cyprus fungi. Technical Bulletin 5. Government of Cyprus, Department of Agriculture, p. 38.

Hebert TT, Clayton CN, 1963. Pomegranate fruit rot caused by Coniella granati. Plant Dis Rep 47:222-223.

Jamadar MM, Sataraddi AR, Patil PV, Jawadagi RS, Patil DR, 2011. Status of pomegranate diseases of Northern Karnataca in India. Acta Horticult 890:501-507.

Kanetis L, Testempasis S, Goulas V, Samuel S, Myresiotis C, Karaoglanidis GS, 2015. Identification and mycotoxigenic capacity of fungi associated with pre- and postharvest fruit rots of pomegranates in Greece and Cyprus. Int $\mathbf{J}$ Food Microbiol 208: 84-92.

Kumari N, Ram V, Sharma I, 2015. Prevalence and management of leaf spot and dry fruit rot (Coniella granati) of pomegranate. Int J Farm Sci 5(2):105-113.

Kumari N, Ram V, 2015. Influence of epidemiological parameters on the development and spread of leaf spot and dry fruit rot (Coniella granati) of pomegranate. Journal of Agrometeorology 17 (2): 259-260.

Kurt S, Dervis S, Sahinler S, 2003. Sensitivity of Verticillium dahliae to prochloraz and prochloraz-manganese complex and control of Verticillium wilt of cotton in the field. Crop Prot 22:51-55.

Labuda R, Hudec K, Piecková E, Mezey J, Bohovic R, Mátéová S, Lukác SS, 2004. Penicillium implicatum causes a destructive rot of pomegranate fruits. Mycopathologia 157, 217-223.

Levy E, Elkind G, Ben-Arie R, Ben-Ze'ev IS, 2011. First report of Coniella granati causing pomegranate fruit rot in Israel. Phytoparasitica 39:403-405.

Michailides TJ, Pucket R, Morgan D, 2010. Pomegranate decay caused by Pilidiella granati in California. Phytopathology 100:S83.

Mirabolfathy M, Groenewald JZ, Crous PW, 2012. First report of Pilidiella granati causing dieback and fruit rot of pomegranate (Punica granatum) in Iran. Plant Dis 96:416.

Munhuweyi K, Lennox CL, Meitz-Hopkins JC, Caleb OJ, Oparaa UL, 2016. Major diseases of pomegranate (Punica granatum L.), their causes and management-A review. Scientia Horticulturae 211: 126-139.

Nerya O, Levin A, 2015. Innovative treatment of pomegranates from harvest to market. Acta Horticult 1089:489-493.

Nerya O, Tzviling A, Hibrahim H, et al.,2016. Coniella granati - a new pathogen of pomegranates in Israel - postharvest fungicide screening for control of storage decay. Acta Horticulturae 1144: 465-467.

Pala H, Tatli A, Yilmaz C, Özgüven AI, 2009. Important diseases of pomegranate fruit and control possibilities in Turkey. Acta Horticult 818:285-289.

Palou L, Guardado A, Montesinos-Herero C, 2010. First report of Penicillium spp. and Pilidiella granati causing postharvest fruit rot of pomegranate in Spain. New Dis Rep 22:21. 
Palou L, Taberner V, Guardado A, Del Rio MA, MonstesinosHerrero C, 2013. Incidence and etiology of postharvest fungal diseases of pomegranate (Punica granatum cv. Mollar de Elche) in Spain. Phytopathol Mediterr 52:478489.

Pollastro S, Dongiovanni C, Gerin D., Pollastro P, Fumarola G, De Miccolis Angelini RM, Faretra F, 2016. First Report of Coniella granati as a Causal Agent of Pomegranate Crown Rot in Southern Italy. Plant Dis 100 (7): 1498.

Richardson MJ, 1990. An Annotated List of Seed Borne Diseases. The International Seed Testing Association Zurich, Switzerland.

Selcuk N, Erkan M, 2014. Changes in antioxidant activity and postharvest quality of sweet pomegranates cv. Hicrannar under modified atmosphere packaging. Postharvest Biol Technol 92:29-36.

Sharma RL, 2005. Management of brown rot (Monilinia laxa) in peaches in warmer areas. Acta Horticult 696: 359-362.

Snowdon AL, 1990. A Color Atlas of Post-harvest Diseases and Disorders of Fruits and Vegetables. Vol. 1: General Introduction and Fruits. CRC Press, Boca Raton, FL, USA, $20 \mathrm{pp}$.

Sutton BC, 1969. Type studies of Coniella, Anthasthoopa and Cyclodomella. Can J Bot 47:603-608.

Thomidis T, Exadaktylou E, 2011. First Report of Pilidiella granati on Pomegranate with Symptoms of Crown Rot in the Prefecture of Xanthi, Greece. Plant Dis 95(1):79.
Teksür PK, Şen F, Yildiz F, Özaltaca N, Selvi AK, Kalın A, 2015. Postharvest fungal pathogens on pomegranate fruit (Punica granatum L. var. hicaz) in cold storage conditions. Phytopathol Mediterr 54 (1):140-196.

Thomidis T, 2014. Fruit rots of pomegranate (cv. Wonderful) in Greece. Australasian Plant Pathology 43: 583-588.

Thomidis T, 2015. Pathogenicity and characterization of Pilidiella granati causing pomegranate diseases in Greece. Eur J Plant Pathol 141:45-50.

TUIK, 2015. Crop Production Statistics. Turkish Statistical Institute, http://www. turkstat.gov.tr/, Ankara, Turkey.

Tziros GT, Tzavella-Klonari K, 2008. Pomegranate fruit rot caused by Coniella granati confirmed in Greece. Plant Pathol. 57, 783.

Van Niekerk JM, Groenewald JZ, Verkley GJM, Fourie PH, Wingfield MJ, \& Crous PW, 2004. Systematic reappraisal of Coniella and Pilidiella, with specific reference to species occurring on Eucalyptus and Vitis in South Africa. Mycological Research, 108, 283-303.

Yildiz M, Karaca I, 1973. Türkiye'de Coniella granati'nin meydana getirdigi nar meyve Cürüklügü. Ege Univ Ziraat Fakültesi Dergisi 10(2):315-325.

Ypema HL, Gold, RE, 1999. Kresoxim-methyl: modifications of a naturally occurring compound to produce a new fungicide. Plant Dis. 83, 4-19. 